\title{
Low inter-basin connectivity in a facultatively diadromous fish: evidence from genetics and otolith chemistry
}

Jane M. Hughes* Daniel J. Schmidt*, Jed I. Macdonald †, Joel A. Huey*, David A.

$$
\text { Crook } \uparrow \S
$$

*Australian Rivers Institute, Griffith University, Nathan, 4111, QLD, Australia.

$\dagger$ Arthur Rylah Institute for Environmental Research, Department of Sustainability and Environment, Heidelberg, Vic 3084, Australia

\$Faculty of Life and Environmental Sciences, University of Iceland, Sturlugata 7, 101 Reykjavík, Iceland

${ }^{\S}$ Research Institute for Environment and Livelihoods, Charles Darwin University, Darwin, NT 0909, Australia

Correspondence: Jane M. Hughes, Fax: +61 (07) 3875 7615; E-mail:

jane.hughes@griffith.edu.au

Keywords: Retropinna, amphidromy, diadromy, microsatellite, connectivity, otolith microchemistry

Running title: Low connectivity in a facultatively diadromous fish 


\section{Abstract}

Southern smelts (Retropinna spp.) in coastal rivers of Australia are facultatively diadromous, with populations potentially containing individuals with diadromous or wholly freshwater life-histories. The presence of diadromous individuals is expected to reduce genetic structuring between river basins due to larval dispersal via the sea. We use otolith chemistry to distinguish between diadromous and non-diadromous life-histories and population genetics to examine inter-basin connectivity resulting from diadromy. Otolith strontium isotope $\left({ }^{87} \mathrm{Sr}:{ }^{86} \mathrm{Sr}\right)$ transects identified three main life history patterns: amphidromy, freshwater residency and estuarine/marine residency. Despite the potential for inter-basin connectivity via larval mixing in the marine environment, we found unprecedented levels of genetic structure for an amphidromous species. Strong hierarchical structure along putative taxonomic boundaries was detected, along with highly structured populations within groups using microsatellites $\left(F_{\mathrm{ST}}=0.046-0.181\right)$, and mtDNA $\left(\Phi_{\mathrm{ST}}=0.498-0.816\right)$. The presence of strong genetic subdivision, despite the fact that many individuals reside in saline water during their early life-history, appears incongruous. However, analysis of multi-elemental signatures in the otolith cores of diadromous fish revealed strong discrimination between river basins, suggesting that diadromous fish spend their early lives within chemically distinct estuaries rather than the more homogenous marine environment, thus avoiding dispersal and maintaining genetic structure.

\section{Introduction}

Connectivity is a key determinant of population structure in nature, and strongly influences the genetic diversity, adaptive potential and resilience of species (Allendorf \& Luikart 2007). There may be strong relationships between the habitats occupied by 
a species and the level of connectivity among local populations. For example, freshwater fish generally have much higher levels of genetic structuring between spatially distinct populations than marine species because of the presence of natural (e.g. mountain ranges) and artificial (e.g. dams) barriers to dispersal in freshwater ecosystems (Ward et al. 1994). Diadromous species (i.e. species that migrate between marine and freshwater) tend to have highly variable levels of population structure, reflecting the wide range of life history strategies exhibited by these species.

There are three widely recognised modes of diadromy in fishes (McDowall 1992; Myers 1949): “catadromous" species spend most of their adult life in freshwater and migrate to the sea to spawn; "anadromous" species spend most of their adult life at sea and migrate to freshwater to spawn; and "amphidromous" species migrate between fresh and marine habitats but not for the purpose of spawning (McDowall 1992). Most amphidromous fishes exhibit "freshwater amphidromy", with spawning occurring in freshwater and the eggs and/or larvae drifting downstream until they reach the estuary and/or the open ocean (McDowall 2007; Thuesen et al. 2011). The juveniles generally return to freshwater after 4-6 months in the estuarine/marine environment and sexual maturation occurs in freshwater. A small number of species are also thought to exhibit "marine amphidromy" in which spawning occurs in the sea and freshwater is utilized by juveniles before migration back to sea (see Gross 1987; McDowall 1988).

Catadromous species tend to exhibit low levels of population structure or panmixia over large geographic scales (e.g. angullid eels, Als et al. 2011), whereas anadromous species are often highly structured due to natal homing (e.g. many salmonids, Vaha et 
al. 2007). Amphidromous species generally exhibit low genetic structuring between populations over moderate spatial scales (i.e. $100 \mathrm{~s}$ of $\mathrm{km}$ ), presumably due to extensive mixing of eggs and/or larvae in the marine environment (Cook et al. 2009; Crandall et al. 2010; Page et al. 2013). For example, the Australian Grayling Prototroctes maraena exhibits obligate amphidromy and is panmictic across southern Victoria, Australia (Schmidt et al. 2011).

Most studies of the population structure of diadromous fishes have categorised the life-history of the study species a priori and then used genetic markers to test the level of among-population connectivity. However, broad categorisations of species may fail to take into consideration important intra-population variation in migratory behaviors. Such variation has been documented for a wide range of diadromous fishes and has been referred to as "facultative diadromy" (Hicks et al. 2010; McDowall 1988). For example, anguillid eels have long been viewed as the "classic" example of catadromy, yet otolith chemistry analyses have shown that many individuals spend their entire lives in the marine environment (Tsukamoto et al. 1998). Similarly, many populations of "anadromous" salmonids contain individuals that live their entire lives within freshwater (Chapman et al. 2012). Facultative migration amongst amphidromous species has received much less attention, although its existence has been confirmed for several species including giant kokopu Galaxias argenteus (Hicks et al. 2010) and common bully Gobiomorphus cotidianus (Closs et al. 2003). The effects of variable life-history on genetic connectivity among populations of fishes that exhibit amphidromy have not been examined. 
Members of the family Retropinnidae (the Southern Hemisphere smelts) exhibit wide variation in life history modes (McDowall 1988). The New Zealand smelt Retropinna retropinna appears to exhibit facultative diadromy, with some individuals within populations undertaking either anadromous or amphidromous migrations, and others residing in freshwater throughout their lives (Northcote \& Ward 1985). However, it is possible that these two forms are different cryptic species, as there is some evidence of reproductive isolation between anadromous and non-diadromous individuals (Northcote \& Ward 1985).

There are currently two recognised species of Southern Hemisphere smelts in Australia. The Australian smelt Retropinna semoni is a primarily freshwater species found in inland and coastal drainages throughout south-eastern Australia. Although most populations of the species are non-diadromous, a recent otolith chemistry study showed that the majority of individuals sampled from a coastal river in southern Victoria had spent their early life history in saline habitats, suggesting these fish were most likely amphidromous or catadromous (Crook et al. 2008). The Tasmanian smelt $R$. tasmanica is found only in the lower reaches of coastal rivers and estuaries in Tasmania. Little is known of the species' life history, although it has been suggested that they exhibit anadromy (Fulton 1990; McDowall 1988). Allozyme analyses of Retropinna from throughout southern Australia recently found that $R$. tasmanica from Tasmania form a clade with $R$. semoni from the Murray Darling Basin and western Victoria, suggesting that $R$. tasmanica may not be a distinct species (Hammer et al. 2007). The analyses of Hammer et al. (2007) also suggest the presence of two or more cryptic Retropinna species, so it is possible that life-history variation corresponds with putatative taxonomic status. Here we examine population genetic structure and 
life-history variation within and between populations of the two currently recognized Australian Retropinna species. However, as taxonomic boundaries are yet to be clarified within Australian Retropinna, we hereafter refer to fish by their geographic location, or more generally as Retropinna spp.

In this study, we use otolith chemistry analysis to examine life-history variation within and among populations of Australian smelt from coastal rivers in southern Victoria and Tasmania, Australia. We also use a combination of mitochondrial sequence data and microsatellite analyses to examine genetic variation among populations in different river basins. The results of the otolith chemistry and genetic analyses are then used to test the hypothesis that populations will be structured genetically when most individuals are non-amphidromous, whereas populations consisting largely of amphidromous individuals will be genetically homogeneous due to mixing via marine dispersal pathways.

\section{Material and methods}

\section{Fish and water collection}

Retropinna spp. were collected using seine or dip nets from the freshwater reaches of 10 coastal rivers in Victoria, and were sampled from the lower freshwater/upper estuarine reaches of four coastal rivers in Tasmania (Table 1; Fig. 1a). Where possible, 30 individuals were sampled from each site for genetic analysis, with a subset of 10 fish per site used for otolith chemistry analysis. Fish were preserved in $100 \%$ ethanol in plastic containers prior to dissection. Water samples were taken for analysis of $\mathrm{Sr}$ isotope ratios $\left({ }^{87} \mathrm{Sr}:{ }^{86} \mathrm{Sr}\right)$ from the 11 rivers where otoliths were sourced (Table 1). Water was sampled in $125 \mathrm{ml}$ acid-washed polyethylene bottles, filtered in 
the field through $0.2 \mu \mathrm{m}$ Acrodisc syringe-mounted filters, acidified with nitric acid and refrigerated at $4^{\circ} \mathrm{C}$. Samples were taken from each catchment at the lowest accessible point upstream of estuarine influence. The ${ }^{87} \mathrm{Sr}:{ }^{86} \mathrm{Sr}$ ratio from this sample was therefore an integration of the water chemistry of the upstream catchment, and represents the first freshwater ${ }^{87} \mathrm{Sr}:{ }^{86} \mathrm{Sr}$ signature encountered by juveniles immigrating upstream from the estuary or sea.

\section{Water and otolith chemistry analysis}

We analysed ${ }^{87} \mathrm{Sr}:{ }^{86} \mathrm{Sr}$ in water and otoliths to discriminate between wholly freshwater and diadromous smelt. ${ }^{87} \mathrm{Sr}:{ }^{86} \mathrm{Sr}$ is essentially invariant in the marine environment (global value: 0.70916, McArthur \& Howarth 2004), but varies widely in fresh water due to heterogeneity in the underlying geology and local hydrology (Barnett-Johnson et al. 2008; Crook et al. 2013). As ${ }^{87} \mathrm{Sr}:{ }^{86} \mathrm{Sr}$ incorporation into otoliths directly reflects ambient water (Amakawa et al. 2012), it is possible to directly match otolith and water ${ }^{87} \mathrm{Sr}:{ }^{86} \mathrm{Sr}$ to determine residence in saline versus freshwater. Fish with ${ }^{87} \mathrm{Sr}:{ }^{86} \mathrm{Sr}$ values close to 0.70916 near the otolith core (i.e. early life history), that subsequently transitioned to values closely reflecting the catchment's freshwater ${ }^{87} \mathrm{Sr}:{ }^{86} \mathrm{Sr}$ value, were identified as diadromous (Schmidt et al. in press).

Water chemistry $-{ }^{87} \mathrm{Sr}:{ }^{86} \mathrm{Sr}$

For water ${ }^{87} \mathrm{Sr}:{ }^{86} \mathrm{Sr}$ analysis, $20 \mathrm{ml}$ aliquots were dried overnight in a HEPA-filtered fume cupboard. Matrix elements were washed off the resin with $2 \mathrm{M}$ and $7 \mathrm{M}$ nitric acid, followed by elution of clean $\mathrm{Sr}$ in $0.05 \mathrm{M}$ nitric acid. Sr isotope analyses were carried out on a "Nu Plasma" multicollector ICP-MS interfaced with an ARIDUS desolvating system (see Maas et al. 2005). Mass bias was corrected by normalizing to 
${ }^{88} \mathrm{Sr}:{ }^{86} \mathrm{Sr}=8.37521$ and results are reported relative to a value of 0.710230 for the SRM987 standard. Internal precisions (2SE) based on at least 30 ten-second integrations averaged $<0.00002$. Reproducibility $(2 \mathrm{SD})$ was $<0.00004$.

Otolith chemistry $-{ }^{87} \mathrm{Sr}:{ }^{86} \mathrm{Sr}$

Sagittal otoliths were removed, cleaned and stored dry in $0.5 \mathrm{~mL}$ polypropylene microtubes. One otolith from each fish was then mounted individually, proximal surface downwards, on an acid-washed glass slide in thermoplastic glue and prepared for ${ }^{87} \mathrm{Sr}:{ }^{86} \mathrm{Sr}$ analysis following the procedures of Schmidt et al. (in press). We measured otolith ${ }^{87} \mathrm{Sr}:{ }^{86} \mathrm{Sr}$ using a "Nu Plasma" multicollector ICP-MS coupled to a HelEx 193 nm ArF excimer laser ablation system (see Woodhead et al. 2005; Schmidt et al. in press for further details). Otoliths were ablated from the core to the dorsal margin at the widest radius using a $6 \times 100 \mu \mathrm{m}$ rectangular laser slit. Preablation was conducted along each transect to remove potential surface contaminants, and data were acquired from a second analysis along the same transect, with the laser operated at $90 \mathrm{~mJ}$, pulsed at $10 \mathrm{~Hz}$ and scanned at $3 \mu \mathrm{m} \mathrm{sec}^{-1}$. A $20-30 \mathrm{sec}$ background was measured prior to data acquisition for each sample. Iolite Version 2.13 (Paton et al. 2011) was used to process data offline, with corrections made for isobaric interferences from $\mathrm{Kr}, \mathrm{Rb}$ and $\mathrm{Ca}$ argide/dimer species following the methods of Woodhead et al. (2005) and Schmidt et al. (in press). Instrumental mass bias was corrected by internal normalisation to ${ }^{88} \mathrm{Sr}:{ }^{86} \mathrm{Sr}=8.37521$. We integrated ${ }^{87} \mathrm{Sr}:{ }^{86} \mathrm{Sr}$ values measured across 2 -sec intervals, resulting in a spatial resolution along the transect of $6 \mu \mathrm{m}$ horizontal distance per integration. A modern marine carbonate standard was analysed after every 10 otolith samples to calculate external precision. Mean $( \pm 1 \mathrm{SD}){ }^{87} \mathrm{Sr}:{ }^{86} \mathrm{Sr}$ in the standard $(n=24)$ was $0.70917 \pm 0.00013$. 


\section{Otolith chemistry - trace elements}

Trace element analyses were also conducted for a subset of the Victorian sites to examine connectivity between diadromous populations. The second otolith of each fish was mounted on a clean glass slide as described above; however, the polishing step was omitted. Vertical ablation transects were run from the distal surface of the otolith to the proximal surface, through the primordium, using the depth profiling method of Macdonald et al. (2008). A suite of elements $\left({ }^{24} \mathrm{Mg},{ }^{43} \mathrm{Ca},{ }^{55} \mathrm{Mn},{ }^{88} \mathrm{Sr}\right.$,

${ }^{138} \mathrm{Ba}$ ) were measured using a Varian 810 quadrupole ICP-MS coupled to the HelEx laser ablation system described above (see also Crook et al. 2013). Otolith core material accreted between 2-10 days post-hatch was selected to represent the environment experienced by the diadromus individuals during early larval life (Macdonald et al. 2008). Data was processed using Iolite Version 2.13 (Paton et al. 2011) and followed standard protocols for background subtraction, normalisation to $\mathrm{Ca}$ and calibration to an external glass standard (National Institute of Standards Technology, NIST 612) (see Crook et al. 2013). Data were expressed as element:Ca molar ratios (i.e. $\mathrm{Mg}: \mathrm{Ca}, \mathrm{Mn}: \mathrm{Ca}, \mathrm{Sr}: \mathrm{Ca}, \mathrm{Ba}: \mathrm{Ca}$ ) and we created a multi-elemental signature for each fish by combining all four molar ratios. Measurement precision (\% relative standard deviation, R.S.D.) was determined based on $(n=9)$ analyses of NIST 610 and MACS-3 $(n=8)$ reference standards. Mean \% R.S.D. was Mg:Ca 2.59/1.58, Mn:Ca 3.19/5.02, Sr:Ca 3.06/2.37, Ba:Ca 3.47/4.52 for NIST 610 and MACS-3 respectively. A single-factor multivariate analysis of variance (MANOVA) and quadratic discriminant function analysis (DFA) were conducted on $\log _{10}$ transformed data to examine variation in multi-elemental signatures among diadromous populations. 
In rivers where the difference between freshwater ${ }^{87} \mathrm{Sr}:{ }^{86} \mathrm{Sr}$ and the global marine value was too small to resolve diadromous movements using this marker alone (i.e. Glenelg River, Darlots Creek, Hopkins River), we also examined otolith Sr:Ca and $\mathrm{Ba}$ :Ca transects across the full life history of individuals using the depth profiling method outlined above. Mn peaks observed during data processing were used as a proxy for the otolith core (Brophy et al. 2004; Macdonald et al. 2008; Ruttenberg et al. 2005), and Sr:Ca and Ba:Ca were integrated across 2-sec intervals..

\section{Genetic methods}

Genomic DNA was extracted from ethanol-preserved tissue samples using a standard salting-out protocol modified for 96-well plate throughput as per Aljanabi and Martinez (1997). A 950bp fragment of mitochondrial DNA spanning ATP synthase subunit 8 and ATP synthase subunit 6 genes was amplified and sequenced using primers and protocols described by Woods et al. (2010). Sequence data was deposited in GenBank under accession numbers KC150089 - KC150135 (Supporting information, Table S1). Additional sequences representing a range of Retropinna geographic localities and outgroups were obtained from GenBank (Hughes \& Hillyer 2006; Ishiguro et al. 2003; Page \& Hughes 2010; Schmidt et al. 2011; Woods et al. 2010). Seven microsatellite loci were amplified and genotyped using the multi-tailed primer tagging method of Real et al. (2009). Microsatellite primer sets included sm26, sm49, sm77, sm80 (Hillyer et al. 2006); smE8, smG7 (Schmidt et al. 2011); and a previously unpublished locus $s m C 7$ ( $s m C 7$ F: GCACCGTATGCCTGTCTACCAC; smC7_R: CATCTGTTGCTGTTGTTGATGGTT). 


\section{Genetic analyses}

For mtDNA data, haplotype diversity $(h)$, nucleotide diversity $(\pi)$ and pairwise estimates of fixation indices $\left(F_{\mathrm{ST}}, \Phi_{\mathrm{ST}}\right)$ among 14 sample sites were calculated using ARLEQUIN v3.5.1.2 (Excoffier \& Lischer 2010). Genealogical relationships among the sampled mtDNA haplotypes were estimated by statistical parsimony using TCS v1.21 (Clement et al. 2000). A gene tree incorporating exemplar haplotypes from each sampled mtDNA clade, outgroups, and published sequences representing variation within Retropinna was reconstructed using BEAST v1.7.4 (Drummond \& Rambaut 2007). A lognormal relaxed clock model was first used to estimate divergence times of ingroup clades. However the data could not reject a strict clock (ucld.stdev included zero), therefore a strict clock model was used along with a coalescent constant size tree prior with a fixed substitution rate of $0.65 \times 10^{-8}$ substitutions/site/year (Bermingham et al. 1997). An appropriate substitution model $($ GTR + I) was selected using MrMODELTEST v2.3 (Nylander 2004). Convergence, mixing and effective sample size of model parameters (>200) was assessed using the program Tracer v1.5 (Drummond \& Rambaut 2007) after running the analysis for $10^{8}$ generations. A maximum clade credibility tree was produced using the programs TreeAnnotator v1.7.4 and Fig Tree v1.3.1 (Drummond \& Rambaut 2007).

For microsatellite data, tests for deviation from Hardy-Weinberg Equilibrium (HWE) for each locus-population combination were carried out using exact tests implemented in ARLEQUIN. Genetic structure was quantified by estimating pair-wise and global $F_{\text {ST }}$ values in ARLEQUIN. These were tested for significant deviation from panmictic expectations by 10,000 permutations of individuals among populations. For significance testing, the critical value $(\alpha)$ was corrected for multiple tests using the 
False Discovery Rate method (FDR, Narum 2006). To examine the contribution of individual population samples to overall $F_{\mathrm{ST}}$ we computed population-specific $F_{\mathrm{ST}}$ values for microsatellite data using GESTE v2.0, (Foll \& Gaggiotti 2006); and for mtDNA by calculating the average pairwise $\Phi_{\mathrm{ST}}$ of each focal population. Populationspecific $F_{\mathrm{ST}}$ analyses were calculated separately for three regional groups of populations that were genetically distinct (West, East, Tasmania; see Results).

Structuring of individual multi-locus genotypes was investigated independently of sample groupings using a model-based Bayesian clustering method. The probability of an admixture model was tested for clusters $(\mathrm{K})$ ranging from one to $15 \mathrm{using}$ STRUCTURE 2.3.1 (Pritchard et al. 2000). Models were tested using eight independent MCMC simulations, each consisting of $2 \times 10^{6}$ iterations after a burn-in of $10^{5}$ iterations. The most likely number of homogeneous clusters was assessed by standardising the second order rate of change of the mean likelihood of $\mathrm{K}$ (i.e. $\Delta \mathrm{K}$, Evanno et al. 2005), using the online application STRUCTURE HARVESTER (Earl \& Vonholdt 2012). A hierarchical approach to STRUCTURE was used (see Vaha et al. 2007).

Contemporary migration rates $(m$, the proportion of immigrants in a focal population that arrive from a source population) over the past few generations were estimated using a Bayesian assignment method implemented in the software BAYESASS v1.3 (Wilson \& Rannala 2003). This method is based on the principle that immigrants and their progeny show temporary disequilibrium in their microsatellite genotypes relative to the focal population under the assumption that background migration rate is relatively low $\left(F_{\mathrm{ST}}>0.05\right)$ and that loci are in linkage equilibrium. To achieve 
convergence and consistency of posterior probability estimates among replicate runs, analyses were run for 60 million iterations, sampling every 2000 with a burn-in of 10 million iterations. Delta values were adjusted to 0.2 to ensure chain swapping occurred in approximately $50 \%$ of the total iterations as recommended by Wilson and Rannala (2003). Unidirectional estimates of $m$ were made for all pairs of sites and rates were reported that fell outside the $95 \%$ confidence interval simulated for uninformative data (Wilson \& Rannala 2003).

\section{Results}

\section{Otolith Chemistry}

Analysis of ${ }^{87} \mathrm{Sr}:{ }^{86} \mathrm{Sr}$ in the otoliths of Retropinna spp. indicated three broad lifehistory patterns: diadromy, freshwater residence and estuarine/marine residence. Samples of mainland Retropinna from the Tarwin, Snowy and Bemm Rivers in Victoria showed evidence of diadromy, with otolith ${ }^{87} \mathrm{Sr}:{ }^{86} \mathrm{Sr}$ close to the global marine value of 0.70916 in the core region and ${ }^{87} \mathrm{Sr}:{ }^{86} \mathrm{Sr}$ closely reflecting the freshwater ${ }^{87} \mathrm{Sr}:{ }^{86} \mathrm{Sr}$ signature near the margin (Fig. 2, traces i, m and o). Diadromous individuals dominated in the three rivers where diadromy was detected, with only two non-diadromous fish observed out of the 30 analyzed. One fish from the Snowy River had ${ }^{87} \mathrm{Sr}:{ }^{86} \mathrm{Sr}$ values indicative of freshwater residence throughout its life (Fig. 2, trace $\mathrm{n}$ ), while one from the Bemm River had ${ }^{87} \mathrm{Sr}:{ }^{86} \mathrm{Sr}$ values indicative of residence in saline water throughout life (Fig. 2, trace p). This latter instance likely indicates that the fish had only recently arrived from the estuarine habitat, as the freshwater collection site on the Bemm River was located immediately ( 200 m) upstream of the estuary. 
Examination of the multi-elemental signatures of the otolith cores (i.e. saline residence phase) of diadromous Retropinna from the Bemm, Snowy and Tarwin rivers demonstrated highly significant differences between rivers (MANOVA: $\mathrm{df}=8$, 42, Pillai's trace $=0.723, P=0.01)$. Jack-knifed classification accuracy from the DFA was $100 \%$ for the Snowy and Bemm, and $89 \%$ for the Tarwin (one fish from the Tarwin was misclassified to the Bemm). The first discriminant function (DF) accounted for $98 \%$ of the variance and Ba was by far the most influential element (standardised coefficients for DF1: $\mathrm{Ba}=1.056 ; \mathrm{Sr}=0.308 ; \mathrm{Mn}=0.131 ; \mathrm{Mg}=-$ $0.006)$.

Mainland Retropinna from the Yarra and Thomson rivers were clearly nondiadromous, with no marine ${ }^{87} \mathrm{Sr}:{ }^{86} \mathrm{Sr}$ in the core region and the ${ }^{87} \mathrm{Sr}:{ }^{86} \mathrm{Sr}$ at the otolith margins closely reflecting the water from which they were sampled (Fig. 2, e.g. traces $\mathrm{g}$ and $\mathrm{k})$. The existence of diadromy in the Glenelg River, Hopkins River and Darlots Creek samples could not be resolved using ${ }^{87} \mathrm{Sr}:{ }^{86} \mathrm{Sr}$ because the freshwater endmember values were too close to the seawater value of 0.7016 to clearly identify shifts in ${ }^{87} \mathrm{Sr}:{ }^{86} \mathrm{Sr}$ between residence in estuarine or marine water and fresh water (Fig. 2, traces a, c and e). Subsequent examination of otolith $\mathrm{Sr}: \mathrm{Ca}$ and Ba:Ca profiles provided no evidence of diadromous movements for any individuals sampled from the three rivers, with stable and relatively low $\mathrm{Sr}$ :Ca values observed $\left(<2.7 \mathrm{mmol} \mathrm{mol}^{-1}\right)$ and the absence of negative relationships between $\mathrm{Ba}: \mathrm{Ca}$ and $\mathrm{Sr}: \mathrm{Ca}$ that can indicate a shift between estuarine or marine and freshwater residence in this species (Fig. 3) (Crook et al. 2008). In contrast, Crook et al. (2008) found clear peaks in Sr:Ca of 3.5 mmol mol ${ }^{-1}$ and strong negative relationships between $\mathrm{Sr}: \mathrm{Ca}$ and $\mathrm{Ba}: \mathrm{Ca}$ in otolith chemistry profiles of diadromous smelt from the Tarwin River. 
Otolith chemistry analysis of Retropinna sp. from the three Tasmanian rivers revealed no evidence of freshwater residence at any stage during life. Otolith ${ }^{87} \mathrm{Sr}:{ }^{86} \mathrm{Sr}$ values were generally close to the global marine value and did not reflect the freshwater ${ }^{87} \mathrm{Sr}:{ }^{86} \mathrm{Sr}$ values of the river basin from which the fish were collected (Fig. 2, traces s and $\mathrm{u}$ ). This pattern suggests that Retropinna sp. from Tasmania have a very different life history strategy to the diadromous and non-diadromous Retropinna collected from mainland Australia (see Discussion).

\section{Genetics}

A total of 255 mtDNA sequences were obtained from fish across 14 coastal rivers (Supporting information, Table S1). The edited alignment was 413 bp in length, including 97 variable positions and 47 haplotypes resolved into four disconnected networks (Clades I-IV, Fig. 1b). Genetic variation was evident within all of the 14 river samples (Fig. 1a; Table 2), and strong phylogeographic structure was evident between the samples (Fig. 1a,b). This phylogeographic pattern consisted of a westeast mainland division centered on Wilson's Promontory (WP, Fig. 1a), dividing the distribution of clades I and II (Fig. 1a,b). Clade III was restricted to the Yarra R. site (Fig. 1a,b); and clade IV was confined to sites from Tasmania (Fig. 1a,b). A single individual sampled from the Tarwin R. on the west side of WP carried Clade II mtDNA and was the only exception to this phylogeographic pattern.

Phylogenetic analysis showed that Retropinna from Tasmania (Clade IV, Fig. 1b) were nested within the paraphyletic mainland Retropinna. The west-east phylogeographic division of clades I and II corresponded with two highly supported 
clades in the gene tree, with mean uncorrected pairwise divergence of $15.3 \%$ corresponding to a median divergence time of 21 million years (Fig. 1b; Supporting information, Table S2, Fig. S1). Clade I haplotypes have a close affinity with $R$. semoni sequences collected from inland rivers of the Murray-Darling Basin. Clade II haplotypes correspond to the southeast coastal (SEC) genetic grouping of $R$. semoni designated by Hammer et al. (2007). Clades III (Yarra R.) and IV (Tasmania) form a strongly supported grouping (posterior probability 0.99 , Fig. 1b) with a mean pairwise divergence of $3.5 \%$.

There was extremely strong mtDNA structure among mainland populations west of WP. Indeed, network and phylogenetic analyses showed the Yarra River population contains a unique mtDNA clade that shares a most recent common ancestor (MRCA) with Tasmanian populations (Fig. 1b; Supporting information Table S2). The four other western rivers also exhibit heterogeneity in haplotype frequencies (Fig. 1a). After correction for multiple tests, all pairwise $\Phi_{\mathrm{ST}}$ values were highly significant, except between the Hopkins and Tarwin Rivers (Supporting information, Table S3). The overall $\Phi_{\mathrm{ST}}$ value among western rivers was 0.816 and all population level $\Phi_{\mathrm{ST}}$ values were very high, especially the Yarra $\left(\Phi_{\mathrm{ST}}=0.93\right.$, Table 2$)$. The eastern mainland populations showed less structure overall $\Phi_{\mathrm{ST}}=0.498, \mathrm{P}<0.001$. The five rivers all shared a common haplotype, but the Thompson River also contained a unique clade (population level $\Phi_{\mathrm{ST}}=0.61$, Table 2 ) and was significantly different from the other four, which were not significantly different from each other. $R$. tasmanica were also less structured than the western mainland group, although there were some differences in frequencies of haplotypes (Table 2; Table S3). 
The STRUCTURE analysis incorporating all individuals suggested the most likely number of clusters was two, one containing all Tasmanian and western mainland populations and the other containing all eastern mainland populations (Fig. 4). When these two groups were analyzed separately, the Tasmania+western cluster was divided into separate Tasmanian and western groups, each of which was further subdivided into a third level of hierarchical structure featuring each of the five western population samples clustering into separate groups (Fig. 4). The eastern group produced two clusters when analyzed in isolation, with the Thomson River population distinct from all others. When the Thompson was removed and the remaining four populations analyzed alone, no further clustering was detected (Fig. 4), although pairwise $F_{\mathrm{ST}}$ values for all eastern populations were significant, except the Snowy versus the Bemm and the Avon versus Macalister (Supporting information, Table S4).

There was remarkable concordance between the microsatellite and mtDNA results in terms of pairwise comparisons, with the exception of the Hopkins and Tarwin, which were not differentiated on mDNA, but were differentiated with microsatellites, possibly due to smaller sample sizes for the mtDNA (Supporting information, Tables S3, S4).

Contemporary migration among the coastal river populations sampled in this study appears very limited. The BAYESASS analysis of microsatellite data revealed only five sampled populations containing individuals that could be distinguished as potential immigrants (Table 1). In cases where migration was detected, the putative source population was a nearby river, for example from the Leven to the Rubicon and Great Forester in Tasmania and from the Macalister to the Avon and the Snowy to the 
Bemm in eastern Victoria (Table 1). In eastern Victoria, some migration was detected from Darlots Creek to the Hopkins. Assignment testing of microsatellite data therefore indicates long distance movement among rivers via the sea is absent or rare in smelt.

\section{Discussion}

Our otolith chemistry analyses demonstrated substantial life-history variation among populations of Retropinna, as hypothesized by Crook et al. (2008). In the Victorian coastal rivers, five of the eight sampled populations consisted entirely of nondiadromous individuals, whilst the remaining populations were dominated by individuals that had spent their early life history in saline waters and had subsequently migrated back upstream into freshwater. As spawning has only ever been recorded in freshwater by this species (Koster \& Dawson 2010), the life history mode of these fish appears to most closely resemble "freshwater amphidromy" (McDowall 1988; Myers 1949). The otolith chemistry analysis of Retropinna collected from Tasmania provided little evidence of residence in freshwater at any time during the life history, with fish appearing to have resided in estuarine and possibly marine waters throughout life. Unlike the Victorian samples that were sampled in freshwater, these fish were collected from the uppermost estuarine reaches of the study systems, and one possibility is that they were sampled before having an opportunity to migrate upstream into freshwater. We consider this unlikely, however, as all of the Tasmanian fish analyzed were greater than $60 \mathrm{~mm}$ TL, which is much larger than the size at which upstream migration in mainland Retropinna has been shown to occur $(\sim 15-40$ mm TL, Crook et al. 2008; Crook and Macdonald unpubl. data). These findings are also consistent with previous descriptions of the distribution of Retropinna in 
Tasmaina, suggesting that they are restricted to estuaries and the lower reaches of rivers (Allen et al. 2002; Fulton 1990). Based on these observations, it would appear that Tasmanian Retropinna have a life-history that occurs primarily within estuarine/marine habitats. A similar habitat association and pattern of genetic structure was found for the co-distributed species Tasmanian whitebait (Lovettia sealii), which also undertakes an annual migration into upper estuarine reaches around the Tasmanian coast (Schmidt et al. in press).

We had predicted that if populations contained wholly freshwater fish only, they would be genetically divergent, whereas if some populations contained amphidromous individuals, populations would be homogeneous or panmictic. This was because all previous studies of species thought to be amphidromous had shown minimal genetic structure over scales much larger than examined here (e.g. Cook et al. 2009; Crandall et al. 2010; Page et al. 2013), so with a mixture of population lifehistories, we predicted that any amphidromous individuals would cause homogeneity among rivers. This prediction was not supported. Rather, we found extreme variation in life-history, ranging from wholly freshwater, to amphidromous to estuarine/marine, as well as extremely high levels of genetic structure. Many of the wholly freshwater populations were highly genetically divergent from all others, suggesting that they had remained isolated for considerable evolutionary time (possibly more than 60,000 years in the case of the Yarra population; supplementary Table S2, lower 95\% HPD). Yet, surprisingly all these rivers have open access to the sea, so amphidromous individuals from other estuaries have had the potential to invade over time but appear not to have done so. Only very limited migration seems to occur between rivers, and then only between nearby rivers. 
These findings present a conundrum. If some populations contain amphidromous individuals, why have these populations not provided a source of migrants into other rivers and therefore prevented genetic divergence? One possible scenario is that the species is capable of natal homing. This has never before been reported in an amphidromous species, although it is common in anadromous species that leave their natal habitat as juveniles (not eggs or larvae as in amphidromy) and return to freshwater as mature adults (Dionne et al. 2008; Fontaine et al. 1997). We have no other evidence to suggest that $R$. semoni is capable of such a feat, but studies on another amphidromous species (Galaxias maculatus) have shown that larvae and juveniles are sensitive to differences in water quality (Hale et al. 2008), so it is possible, though unlikely, that juvenile smelt can identify chemical cues from their natal river. Furthermore, larvae of a number of coral reef fish species, which also disperse as eggs and larvae, have been shown to be capable of natal homing (Thorrold et al. 2001).

Alternatively, it has been suggested by a number of authors that selection against immigrants can promote genetic structure among populations (Hendry 2004; Nosil et al. 2005). This hypothesis predicts that local adaptation results in residents having higher fitness in a given habitat than immigrants that will not be adapted to the new environment. Bradbury et al. (2008) showed that in the anadromous rainbow smelt Osmerus mordax, population structure among rivers was much more pronounced in spawning adults than in juveniles and suggested that selection was resulting in immigrant juveniles not surviving to spawning age. It seems unlikely that such a mechanism could explain the results observed here though. In their study, $F_{\mathrm{ST}}$ values 
were between 0.001 and 0.05 , much smaller than observed for some populations in our study.

A final possibility is that individuals that resided in saline water during the early life history are retained within the estuary of their natal river basin: that is, they are only “marginally amphidromous" (sensu McDowall 1988). This suggestion is strongly supported by the multi-elemental otolith analyses - the highly significant inter-basin variation in trace element signatures in the otolith cores (representing the saline residence phase) of amphidromous fish suggests that they most likely resided in saline water within the estuary of their natal catchment, rather than in the more chemically homogenous open ocean. This contrasts with findings for the closely related Australian grayling Prototroctes maraena from coastal Victorian streams where there were no significant differences in otolith core chemistry between spatially distinct samples (Crook et al. 2006). Subsequent genetic analyses of Australian grayling demonstrated panmixia among samples, further supporting the contention that they spend their early life history in the ocean and are, thus, amphidromous (Koster et al. 2013; Schmidt et al. 2011).

Recent studies of some northern hemisphere estuarine species have suggested that larval retention within estuaries can occur through vertical migration of individuals correlated with tides (Bilton et al. 2002). However, even where such mechanisms have been proposed, such as in the sand goby (Pomatoschistus minutus), the levels of genetic structure are considerably lower than those observed here for the smelt $\left(F_{\mathrm{ST}}=\right.$ 0.026 for sand goby versus mean population $F_{\mathrm{ST}}=0.19$ for western mainland and $F_{\mathrm{ST}}$ $=0.07$ for eastern mainland smelt). Presumably this is because, even though most 
sand goby larvae are contained within the estuary, occasionally a small number of individuals are washed to the sea and result in limited mixing. This appears to happen very rarely for southern smelts.

While there are clearly differences among populations in terms of both life-history and genetic distinctness, there also appear to be more general differences, at least between the two mainland groups east and west of Wilson's Promontory, a major biogeographic break point in the Australian marine fauna (see Supporting information, discussion S1). This geographic division coincides with a putative species-level boundary identified by Hammer et al. (2007) within the taxon currently referred to as $R$. semoni. The western group (clade I, Fig. 1a,b) contained a greater proportion of non-diadromous populations than the eastern group (clade II, Fig. 1a,b). Whether this reflects a real difference in life-history characteristics between the two groups would needs to be confirmed with additional otolith analysis. The patterns in Tasmania (clade IV, Fig. 1a,b) are different again, with no fish showing evidence of having spent time in fresh water, yet there is still significant genetic structure and $95 \%$ confidence intervals of all population level $F_{\mathrm{ST}}$ values do not overlap with zero. This suggests that even this group of populations, currently recognized as $R$. tasmanica and suggested by McDowall (1996) to be anadromous, show evidence of limited dispersal among estuaries.

In conclusion, our findings of strong genetic structure between populations of smelt, despite the potential for marine dispersal, contrast with the findings of previous studies of amphidromous organisms (e.g. Cook et al. 2012; Dennenmoser et al. 2010). The drivers of this highly unusual genetic structuring are unclear at present. Previous 
research has suggested that the expression of amphidromous life histories is strongly influenced by the physical attributes of the river basin, with steep, hydrologically unstable systems more likely to encourage amphidromy than gradually sloping, hydrologically stable systems (Thuesen et al. 2011). Our findings of life history variation at large spatial scales and in accordance with putative taxonomic boundaries (e.g. wholly freshwater and amphidromous in Victoria versus estuarine/marine in Tasmania) suggest that local environmental factors are not the sole drivers of life history variation in smelt. A future research need in this area is to determine the extent to which behavioural and environmental factors interact to influence life history expression and dispersal, and thus, regulate population structure.

\section{Acknowledgements}

Funding for this study was provided by an Australian Research Council Linkage grant LP0883429 to JMH and DAC with the support of the Victorian Department of Sustainability and Environment, Queensland Department of Natural Resources and

Water, Melbourne Water and the Tasmanian Inland Fisheries Service. Assistance with genetic laboratory work was provided by Kathryn Real and Amy Dorrington. Ryan Woods provided access to unpublished microsatellite primers for locus smC7. Rhys Coleman, Jonathan Marshall and Stuart Chilcott provided technical input and advice on project design. Jon Woodhead (Melbourne University) provided technical input and assistance with the otolith chemistry analyses and Roland Maas (Melbourne University) analysed the water samples. The paper was improved by comments from two anonymous reviewers. 


\section{References}

Aljanabi SM, Martinez I (1997) Universal and rapid salt-extraction of high quality genomic DNA for PCR-based techniques. Nucleic Acids Research 25, 46924693.

Allen GR, Midgley SH, Allen M (2002) Field guide to the freshwater fishes of Australia Western Australian Museum, Perth.

Allendorf FW, Luikart G (2007) Conservation and the genetics of populations Blackwell Publishing, Malden, MA.

Als TD, Hansen MM, Maes GE, et al. (2011) All roads lead to home: panmixia of European eel in the Sargasso Sea. Molecular Ecology 20, 1333-1346.

Amakawa H, Suzuki T, Takahashi T, Tatsumi Y, Otake T (2012) Sr isotopic compositions of ayu otolith and its ambient water. Fisheries Science 78, 10231029.

Barnett-Johnson R, Pearson TE, Ramos FC, Grimes CB, MacFarlane RB (2008) Tracking natal origins of salmon using isotopes, otoliths, and landscape geology. Limnology and Oceanography 53, 1633-1642.

Bermingham E, McCafferty S, Martin A (1997) Fish biogeography and molecular clocks: perspectives from the Panamanian Isthmus. In: Molecular systematics of fishes (eds. Kocher T, Stepien C), pp. 113-126. Academic Press, New York.

Bilton D, Paula J, Bishop J (2002) Dispersal, genetic differentiation and speciation in estuarine organisms. Estuarine, Coastal and Shelf Science 55, 937-952.

Bradbury IR, Campana SE, Bentzen P (2008) Estimating contemporary early lifehistory dispersal in an estuarine fish: integrating molecular and otolith elemental approaches. Molecular Ecology 17, 1438-1450.

Brophy D, Jeffries T, Danilowicz B (2004) Elevated manganese concentrations at the cores of clupeid otoliths: possible environmental, physiological, or structural origins. Marine Biology 144, 779-786.

Chapman BB, Skov C, Hulthen K, et al. (2012) Partial migration in fishes: definitions, methodologies and taxonomic distribution. Journal of Fish Biology 81, 479-499.

Clement M, Posada D, Crandall KA (2000) TCS: a computer program to estimate gene genealogies. Molecular Ecology 9, 1657-1659.

Closs GP, Smith M, Barry B, Markwitz A (2003) Non-diadromous recruitment in coastal populations of common bully (Gobiomorphus cotidianus). New Zealand Journal of Marine and Freshwater Research 37, 301-313.

Cook BD, Bernays S, Pringle CM, Hughes JM (2009) Marine dispersal determines the genetic population structure of migratory stream fauna of Puerto Rico: evidence for island-scale population recovery processes. Journal of the North American Benthological Society 28, 709-718.

Cook BD, Page TJ, Hughes JM (2012) Phylogeography of related diadromous species in continental and island settings, and a comparison of their potential and realized dispersal patterns. Journal of Biogeography 39, 421-430.

Crandall ED, Taffel JR, Barber PH (2010) High gene flow due to pelagic larval dispersal among South Pacific archipelagos in two amphidromous gastropods (Neritomorpha: Neritidae). Heredity 104, 563-572. 
Crook DA, Macdonald JI, McNeil DG, et al. (2013) Recruitment sources and dispersal of an invasive fish in a large river system as revealed by otolith chemistry analysis. Canadian Journal of Fisheries and Aquatic Sciences 70, 953-963.

Crook DA, Macdonald JI, O’Connor JP, Barry B (2006) Use of otolith chemistry to examine patterns of diadromy in the threatened Australian grayling Prototroctes maraena. Journal of Fish Biology 69, 1330-1344.

Crook DA, Macdonald JI, Raadik TA (2008) Evidence of diadromous movements in a coastal population of southern smelts (Retropinninae : Retropinna) from Victoria, Australia. Marine and Freshwater Research 59, 638-646.

Dennenmoser S, Thiel M, Schubart CD (2010) High genetic variability with no apparent geographic structuring in the mtDNA of the amphidromous river shrimp Cryphiops caementarius (Decapoda: Palaemonidae) in northerncentral Chile. Journal of Crustacean Biology 30, 762-766.

Dionne M, Caron F, Dodson JJ, Bernatchez L (2008) Landscape genetics and hierarchical genetic structure in Atlantic salmon: the interaction of gene flow and local adaptation. Molecular Ecology 17, 2382-2396.

Drummond AJ, Rambaut A (2007) BEAST: Bayesian evolutionary analysis by sampling trees. Bmc Evolutionary Biology 7, 214.

Earl DA, Vonholdt BM (2012) STRUCTURE HARVESTER: a website and program for visualizing STRUCTURE output and implementing the Evanno method. Conservation Genetics Resources 4, 359-361.

Evanno G, Regnaut S, Goudet J (2005) Detecting the number of clusters of individuals using the software STRUCTURE: a simulation study. Molecular Ecology 14, 2611-2620.

Excoffier L, Lischer HEL (2010) Arlequin suite ver 3.5: a new series of programs to perform population genetics analyses under Linux and Windows. Molecular Ecology Resources 10, 564-567.

Foll M, Gaggiotti O (2006) Identifying the environmental factors that determine the genetic structure of populations. Genetics 174, 875-891.

Fontaine P-M, Dodson JJ, Bernatchez L, Slettan A (1997) A genetic test of metapopulation structure in Atlantic salmon (Salmo salar) using microsatellites. Canadian Journal of Fisheries and Aquatic Sciences 54, 24342442.

Fulton W (1990) Tasmanian freshwater fishes Fauna of Tasmania Committee, University of Tasmania.

Hale R, Downes BJ, Swearer SE (2008) Habitat selection as a source of inter-specific differences in recruitment of two diadromous fish species. Freshwater Biology 53, 2145-2157.

Hammer MP, Adams M, Unmack PJ, Walker KF (2007) A rethink on Retropinna: conservation implications of new taxa and significant genetic sub-structure in Australian smelts (Pisces: Retropinnidae). Marine and Freshwater Research 58, 327-341.

Hendry AP (2004) Selection against migrants contributes to the rapid evolution of ecologically dependent reproductive isolation. Evolutionary Ecology Research 6, 1219-1236.

Hicks AS, Closs GP, Swearer SE (2010) Otolith microchemistry of two amphidromous galaxiids across an experimental salinity gradient: A multielement approach for tracking diadromous migrations. Journal of experimental marine biology and ecology 394, 86-97. 
Hillyer MJ, Woods RJ, Hughes JM (2006) Isolation and characterization of polymorphic microsatellite loci in the Australian smelt, Retropinna semoni. Molecular Ecology Notes 6, 224-226.

Hughes J, Hillyer M (2006) Mitochondrial DNA and allozymes reveal high dispersal abilities and historical movement across drainage boundaries in two species of freshwater fishes from inland rivers in Queensland, Australia. Journal of Fish Biology 68, 270-291.

Ishiguro NB, Miya M, Nishida M (2003) Basal euteleostean relationships: a mitogenomic perspective on the phylogenetic reality of the "Protacanthopterygii". Molecular phylogenetics and evolution 27, 476-488.

Koster W, Dawson D (2010) Investigation of Australian grayling spawning in the Yarra and Bunyip rivers, p. 14. Unpublished report to Melbourne Water, Arthur Rylah Institute for Environmental Research, Victoria.

Koster W, Dawson D, Crook D (2013) Downstream spawning migration by the amphidromous Australian grayling (Prototroctes maraena) in a coastal river in south-eastern Australia. Marine and Freshwater Research 64, 31-41.

Maas R, Kamenetsky MB, Sobolev NV (2005) Sr-Nd-Pb isotopic evidence for a mantle origin of alkali chlorides and carbonates in the Udachnaya kimberlite, Siberia. Geology 35, 549-552.

Macdonald JI, Shelley JMG, Crook DA (2008) A method for improving the estimation of natal chemical signatures in otoliths. Transactions of the American Fisheries Society 137, 1674-1682.

McArthur JM, Howarth RJ (2004) Sr-isotope stratigraphy: the Phanerozoic 87Sr/86Sr-curve and explanatory notes. In: A Geological Timescale 2004 (eds. Gradstein F, Ogg J, Smith AG), pp. 96-105. Cambridge University Press, Cambridge.

McDowall RM (1988) Diadromy in fishes: migrations between freshwater and marine environments Timber Press, Portland.

McDowall RM (1992) Diadromy: origins and definitions of terminology. Copeia 1992, 248-251.

McDowall RM (1996) Family Aplochitonidae Tasmanian Whitebait. In: Freshwater Fishes of South-Eastern Australia (ed. McDowall RM), pp. 78-80. Reed Books Australia, Sydney.

McDowall RM (2007) On amphidromy, a distinct form of diadromy in aquatic organisms. Fish and Fisheries 8, 1-13.

Myers GS (1949) Usage of anadromous, catadromous and allied terms for migratory fishes. Copeia 89-97.

Narum SR (2006) Beyond Bonferroni: less conservative analyses for conservation genetics. Conservation Genetics 7, 783-787.

Northcote TG, Ward FJ (1985) Lake resident and migratory smelt, Retropinna retropinna (Richardson), of the lower Waikato River system, New Zealand. Journal of Fish Biology 27, 113-129.

Nosil P, Vines TH, Funk DJ (2005) Perspective: Reproductive isolation caused by natural selection against immigrants from divergent habitats. Evolution 59, 705-719.

Nylander J (2004) MrModeltest v2. Program distributed by the author. Evolutionary Biology Centre, Uppsala University.

Page TJ, Hughes JM (2010) Comparing the performance of multiple mitochondrial genes in the analysis of Australian freshwater fishes. Journal of Fish Biology 77, 2093-2122. 
Page TJ, Torati LS, Cook BD, et al. (2013) Invertebres Sans Frontieres: Large Scales of Connectivity of Selected Freshwater Species among Caribbean Islands. Biotropica 45, 236-244.

Paton C, Hellstrom J, Paul B, Woodhead J, Hergt J (2011) Iolite: Freeware for the visualisation and processing of mass spectrometric data. Journal of Analytical Atomic Spectrometry 26, 2508-2518.

Pritchard JK, Stephens M, Donnelly P (2000) Inference of population structure using multilocus genotype data. Genetics 155, 945-959.

Real KM, Schmidt DJ, Hughes JM (2009) Mogurnda adspersa microsatellite markers: multiplexing and multi-tailed primer tagging. Conservation Genetics Resources 1, 411-414.

Ruttenberg BI, Hamilton SL, Hickford MJ, et al. (2005) Elevated levels of trace elements in cores of otoliths and their potential for use as natural tags. Marine Ecology-Progress Series 297.

Schmidt DJ, Crook DA, Macdonald JI, et al. (in press) Migration history and stock structure of two putatively diadromous teleost fishes, as determined by genetic and otolith chemistry analyses. Freshwater Science.

Schmidt DJ, Crook DA, O'Connor JP, Hughes JM (2011) Genetic analysis of threatened Australian grayling Prototroctes maraena suggests recruitment to coastal rivers from an unstructured marine larval source population. Journal of Fish Biology 78, 98-111.

Thorrold SR, Latkoczy C, Swart PK, Jones CM (2001) Natal homing in a marine fish metapopulation. Science 291, 297-299.

Thuesen PA, Ebner BC, Larson H, et al. (2011) Amphidromy links a newly documented fish community of Continental Australian streams, to Oceanic Islands of the west Pacific. PloS one 6, e26685.

Tsukamoto K, Nakai I, Tesch W-V (1998) Do all freshwater eels migrate? Nature 396, 635-636.

Vaha JP, Erkinaro J, Niemela E, Primmer CR (2007) Life-history and habitat features influence the within-river genetic structure of Atlantic salmon. Molecular Ecology 16, 2638-2654.

Ward RD, Woodwark M, Skibinski DOF (1994) A comparison of genetic diversity levels in marine, fresh-water, and anadromous fishes. Journal of Fish Biology 44, 213-232.

Wilson GA, Rannala B (2003) Bayesian inference of recent migration rates using multilocus genotypes. Genetics 163, 1177-1191.

Woods RJ, Macdonald JI, Crook DA, Schmidt DJ, Hughes JM (2010) Contemporary and historical patterns of connectivity among populations of an inland river fish species inferred from genetics and otolith chemistry. Canadian Journal of Fisheries and Aquatic Sciences 67, 1098-1115. 


\section{Data Accessibility}

DNA sequences: Genbank accessions KC150089 - KC150135

Otolith ${ }^{87} \mathrm{Sr}:{ }^{86} \mathrm{Sr}$ profiles, microsatellite genotype data and mitochondrial DNA sequence alignment: Dryad entry doi:10.5061/dryad.3dh2c

\section{Figure Captions}

Figure 1. Study area and mtDNA variation in Retropinna spp. (a) Map of study area showing position of 14 sampled coastal rivers. Inset map shows position of study area on the Australian continent with Murray-Darling Basin (MDB) in grey. Frequency pies show distribution of mtDNA haplotypes coloured according to haplotype network in Fig. 1b. Uncoloured pie segments correspond to singleton haplotypes. Arrow marks the position of Wilson's Promontory (WP); (b) Maximum clade credibility tree showing relationships among mtDNA clades and matching haplotype networks showing relationships among the full set of sampled haplotypes within each clade. Exemplar sequences from the literature are designated by their GenBank accession number. Letter codes applied to clades correspond to putative taxa proposed by Hammer et al. (2007): MTV, Murray-Darling Basin+Tasmania+western coastal Victoria; COO, Cooper Creek River Basin; SEQ, south-east Queensland; SEC, southeast coast. Uncoloured haplotypes represent singletons. Smelt illustration used under licence $($ ) R.Swainston-anima.net. 
Figure 2. Strontium isotope ratios $\left({ }^{87} \mathrm{Sr}:{ }^{86} \mathrm{Sr}\right)$ for fish collected from 11 rivers in Victoria and Tasmania, Australia (see Fig. 1a). Dashed lines show the water ${ }^{87} \mathrm{Sr}{ }^{86} \mathrm{Sr}$ value for sea-water. Solid lines show the ${ }^{87} \mathrm{Sr}:{ }^{86} \mathrm{Sr}$ value for the freshwater from the sampled catchment. Marine ${ }^{87} \mathrm{Sr}:{ }^{86} \mathrm{Sr}$ is invariant, whereas freshwater ${ }^{87} \mathrm{Sr}:{ }^{86} \mathrm{Sr}$ reflects local geology and may be higher or lower than the marine value. Otolith transects were run from the core to the edge of the otolith. Each vertical bar represents an individual fish and shows the range of values across the transect. Open circles represent the value at the otolith core and closed triangles represent the value at the otolith edge. Representative transects for each population are shown below the bar graphs.

Figure 3. Core to edge transects of otolith $\mathrm{Sr}: \mathrm{Ca}$ (black line, left hand y-axis) and $\mathrm{Ba}: \mathrm{Ca}$ (grey line, right hand y-axis) for $R$. semoni captured from the Glenelg River (a,b), Darlots Creek (c,d) and the Hopkins River (e,f).

Figure 4. STRUCTURE plot showing admixture proportion of 392 individuals genotyped with seven microsatellite loci. Three hierarchical levels of analysis are shown. Population abbreviations: Tho, Thomson; Mac, Macalister; Avo, Avon; Sno, Snowy; Bem, Bemm; Dar. Darlots; Hop, Hopkins; Yar, Yarra; Tar, Tarwin; Lev, Leven; Rub, Rubicon; Gre, Great Forester; Der, Derwent. 


\section{Author contributions}

JMH and DAC conceived and designed the study. DJS, JIM, DAC, JAH collected data and performed data analyses. JMH, DAC, DJS wrote manuscript with contributions from all authors. 
Table 1. Summary of water, otolith and genetic samples analysed and genetic variation in populations of Retropinna spp. based on mitochondrial DNA (mtDNA) and microsatellite markers. Number of specimens $(N)$; Observed heterozygosity $\left(H_{\mathrm{O}}\right)$ and expected heterozygosity $\left(H_{\mathrm{E}}\right)$ presented as mean across all loci with one standard deviation; haplotype diversity $(h)$ and nucleotide diversity $(\pi)$ presented as mean $\pm \mathrm{SD}$. Water ${ }^{87} \mathrm{Sr}:{ }^{86} \mathrm{Sr}$ values are point estimates or mean $\pm \mathrm{SD}$ where replicate samples were taken.

\begin{tabular}{|c|c|c|c|c|c|c|c|c|c|}
\hline \multirow[t]{2}{*}{ River } & \multirow{2}{*}{$\begin{array}{l}\text { Latitude, } \\
\text { Longitude }\end{array}$} & \multicolumn{2}{|c|}{ Otoliths } & \multicolumn{3}{|c|}{ Microsatellites } & \multicolumn{3}{|c|}{ mtDNA } \\
\hline & & $N$ & Water ${ }^{87} \mathrm{Sr}:{ }^{86} \mathrm{Sr}$ & $N$ & $\boldsymbol{H}_{O}$ & $\boldsymbol{H}_{E}$ & $N$ & $h$ & $\pi$ \\
\hline Glenelg & $\begin{array}{l}\mathrm{S} 38^{\circ} 03.108^{\prime} \\
\mathrm{E} 141^{\circ} 00.408^{\prime}\end{array}$ & 10 & 0.709536 & 8 & $0.625 \pm 0.298$ & $0.692 \pm 0.150$ & 8 & $0.679 \pm 0.122$ & $0.00476 \pm 0.00342$ \\
\hline Darlots & $\begin{array}{l}\mathrm{S} 38^{\circ} 13.186^{\prime} \\
\mathrm{E}^{\prime} 141^{\circ} 46.233^{\prime}\end{array}$ & 10 & $0.708339 \pm 0.000159$ & 31 & $0.548 \pm 0.167$ & $0.626 \pm 0.180$ & 20 & $0.190 \pm 0.108$ & $0.00046 \pm 0.00068$ \\
\hline Hopkins & 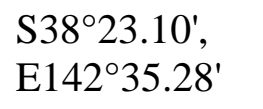 & 10 & $0.709457 \pm 0.000191$ & 29 & $0.640 \pm 0.304$ & $0.659 \pm 0.316$ & 19 & $0.661 \pm 0.084$ & $0.00218 \pm 0.00177$ \\
\hline Yarra & $\begin{array}{l}\text { S37 } 7^{\circ} 51.00^{\prime} \\
\mathrm{E}^{\prime} 144^{\circ} 54.00^{\prime}\end{array}$ & 10 & 0.714086 & 18 & $0.417 \pm 0.376$ & $0.403 \pm 0.373$ & 17 & $0.324 \pm 0.136$ & $0.00082 \pm 0.00096$ \\
\hline Tarwin & $\begin{array}{l}\text { S38 } 39.861^{\prime} \\
\text { E145'56.651' }\end{array}$ & 10 & $0.705729 \pm 0.000017$ & 36 & $0.528 \pm 0.267$ & $0.629 \pm 0.286$ & 13 & $0.872 \pm 0.054$ & $0.02729 \pm 0.01490$ \\
\hline Thomson & $\begin{array}{l}\mathrm{S} 38^{\circ} 08.399^{\prime} \\
\mathrm{E} 147^{\circ} 04.738^{\prime}\end{array}$ & 10 & 0.71755 & 29 & $0.424 \pm 0.225$ & $0.525 \pm 0.272$ & 15 & $0.733 \pm 0.067$ & $0.00826 \pm 0.00501$ \\
\hline Macalister & $\begin{array}{l}\text { S37 } 46.558^{\prime} \\
\text { E}^{\prime} 144^{\circ} 40.175^{\prime}\end{array}$ & - & - & 30 & $0.690 \pm 0.163$ & $0.794 \pm 0.105$ & 19 & $0.538 \pm 0.133$ & $0.00150 \pm 0.00138$ \\
\hline Avon & $\begin{array}{l}\text { S37 } 55.141^{\prime} \\
\text { E}^{\prime} 144^{\circ} 00.757^{\prime}\end{array}$ & - & - & 30 & $0.671 \pm 0.146$ & $0.762 \pm 0.149$ & 24 & $0.312 \pm 0.121$ & $0.00081 \pm 0.00093$ \\
\hline Snowy & $\begin{array}{l}\text { S37 } 42.618^{\prime} \\
\text { E148 }\end{array}$ & 10 & 0.714634 & 35 & $0.678 \pm 0.157$ & $0.764 \pm 0.139$ & 21 & $0.186 \pm 0.110$ & $0.00046 \pm 0.00068$ \\
\hline Bemm & $\begin{array}{l}\mathrm{S} 37^{\circ} 36.462^{\prime} \\
\mathrm{E} 148^{\circ} 54.061^{\prime}\end{array}$ & 10 & $0.718793 \pm 0.000215$ & 31 & $0.733 \pm 0.151$ & $0.776 \pm 0.154$ & 17 & $0.515 \pm 0.145$ & $0.00142 \pm 0.00134$ \\
\hline Leven & $\begin{array}{l}\text { S41 } 09.941^{\prime}, \\
\text { E146이․ }\end{array}$ & - & - & 30 & $0.600 \pm 0.408$ & $0.597 \pm 0.359$ & 26 & $0.523 \pm 0.116$ & $0.00182 \pm 0.00154$ \\
\hline
\end{tabular}




\begin{tabular}{|c|c|c|c|c|c|c|c|c|c|}
\hline \multirow[t]{2}{*}{ River } & \multirow{2}{*}{$\begin{array}{l}\text { Latitude, } \\
\text { Longitude }\end{array}$} & \multicolumn{2}{|c|}{ Otoliths } & \multicolumn{3}{|c|}{ Microsatellites } & \multicolumn{3}{|c|}{ mtDNA } \\
\hline & & $N$ & Water ${ }^{87} \mathrm{Sr}:{ }^{86} \mathrm{Sr}$ & $N$ & $\boldsymbol{H}_{\boldsymbol{O}}$ & $\boldsymbol{H}_{E}$ & $N$ & $\boldsymbol{h}$ & $\pi$ \\
\hline Rubicon & $\begin{array}{l}\text { S41 }{ }^{\circ} 24.074^{\prime}, \\
\text { E146 } 36.349^{\prime}\end{array}$ & 10 & 0.705645 & 30 & $0.486 \pm 0.307$ & $0.581 \pm 0.303$ & 15 & $0.629 \pm 0.124$ & $0.00244 \pm 0.00195$ \\
\hline $\begin{array}{l}\text { Great } \\
\text { Forester }\end{array}$ & $\begin{array}{l}\mathrm{S} 41^{\circ} 02.766^{\prime} \\
\mathrm{E} 147^{\circ} 37.516^{\prime}\end{array}$ & 10 & 0.714036 & 27 & $0.497 \pm 0.339$ & $0.570 \pm 0.334$ & 21 & $0.771 \pm 0.073$ & $0.00270 \pm 0.00205$ \\
\hline Derwent & $\begin{array}{l}\mathrm{S} 42^{\circ} 45.544^{\prime}, \\
\mathrm{E} 147^{\circ} 00.480^{\prime}\end{array}$ & 10 & 0.709885 & 28 & $0.658 \pm 0.304$ & $0.707 \pm 0.297$ & 20 & $0.711 \pm 0.089$ & $0.00335 \pm 0.00240$ \\
\hline
\end{tabular}


Table 2. Estimates of mean population-specific genetic fixation indices for 14 populations of Retropinna spp. and estimates of contemporary migration rates $(m)$ for each river sample. Population-specific fixation indices were calculated separately for three regional groups (West, East, Tasmania) using the microsatellite $\left(F_{\mathrm{ST}}\right)$ and mtDNA $\left(\Phi_{\mathrm{ST}}\right)$ datasets. Migration rate estimates were based on unidirectional assignment of microsatellite genotypes in BAYESASS v1.3. Proportion of non-migrant values represent the proportion of individuals assigned back to their river of origin; mean and $95 \%$ CI values for uninformative data was $0.833(0.675,0.992)$. Putative source of migrants represents source population supplying migrants into the focal population where the estimated migration rate exceeds the upper $95 \%$ CI value for uninformative data (0.104). Migration rates and source of migrants were not provided for cases where the $95 \%$ CI of estimated migration rate overlapped with the $95 \%$ CI value for uninformative data.

\begin{tabular}{|c|c|c|c|c|c|c|}
\hline Region & $\begin{array}{l}\text { Focal } \\
\text { River }\end{array}$ & $\begin{array}{l}\text { microsatellite } \\
F_{\mathrm{ST}}\end{array}$ & $\operatorname{mtDNA} \Phi_{\mathrm{ST}}$ & $\begin{array}{l}\text { Proportion of } \\
\text { non-migrants }\end{array}$ & $\begin{array}{l}\text { Putative source } \\
\text { of migrants }\end{array}$ & $\begin{array}{l}\text { Migration rate }(m) \text {, } \\
\text { mean }(95 \% \mathrm{CI})\end{array}$ \\
\hline \multirow[t]{5}{*}{ West } & Glenelg & 0.159 & 0.635 & 0.704 & - & - \\
\hline & Darlots & 0.261 & 0.585 & 0.990 & - & - \\
\hline & Hopkins & 0.089 & 0.507 & 0.678 & Darlots & $0.265(0.197,0.319)$ \\
\hline & Yarra & 0.329 & 0.934 & 0.983 & - & - \\
\hline & Tarwin & 0.113 & 0.295 & 0.988 & - & - \\
\hline \multirow[t]{5}{*}{ East } & Thomson & 0.196 & 0.609 & 0.977 & - & - \\
\hline & Macalister & 0.052 & 0.151 & 0.984 & - & - \\
\hline & Avon & 0.038 & 0.156 & 0.678 & Macalister & $0.261(0.191,0.321)$ \\
\hline & Snowy & 0.064 & 0.156 & 0.990 & - & - \\
\hline & Bemm & 0.043 & 0.149 & 0.677 & Snowy & $0.273(0.211,0.321)$ \\
\hline \multirow[t]{5}{*}{ Tasmania } & Leven & 0.053 & 0.370 & 0.989 & - & - \\
\hline & Rubicon & 0.132 & 0.361 & 0.687 & Leven & $0.240(0.135,0.316)$ \\
\hline & Great & 0.127 & 0.296 & 0.679 & Leven & $0.277(0.213,0.323)$ \\
\hline & Forester & & & & & \\
\hline & Derwent & 0.037 & 0.825 & 0.985 & - & - \\
\hline
\end{tabular}


